\title{
The Application of Flipped Classroom Teaching Mode in Vocational Colleges
}

\author{
Miaoting Wang, Yaqin Song \\ Shaanxi Technical College of Finance \& Economics, Shaanxi, China, 712000
}

Keywords: Flipped classroom teaching mode; Vocational colleges; application

Abstract: The cultivation of students' learning interest and initiative has become the key content in the current class. High-quality skilled talents have become the goal of classroom teaching reform in vocational colleges. However, flipped classroom pays more attention on the joint effect of dual master mode, which has been widely applied in some vocational colleges and achieved good results. This paper first introduces the concept, characteristics, principles and design process of flipped classroom teaching mode. Finally, some countermeasures are proposed for the effectiveness of flipped classroom teaching, which is expected to improve the classroom teaching effect of vocational colleges.

\section{Introduction}

With the rapid development of information technology, education modernization mode also develops rapidly. As an innovative teaching mode, flipped classroom has become increasingly dominant, which is prevalent in the world. The teaching mode are the following steps. First, teachers make video courseware before class. Second, students use the Internet to watch video and learn in their spare time. Third, teachers and students communicate face to face in class and complete homework. This teaching mode fundamentally changes the traditional teaching mode. This mode enhances students' self-knowledge, teacher-student interaction and individualized teaching. It emphasizes that students are the real subjects in the teaching process. However, it needs many conditions that the introduction of this international advanced teaching mode in the classroom of vocational colleges. Such as, combining the characteristics of students, learning from the conditions in the process of running a school. This paper mainly explores the application of "flipped classroom" teaching methods and means in vocational colleges. Which will be helpful for further deepen the education teaching reform and promoting curriculum construction and reform.

\section{The definition and function of flipped classroom}

\subsection{The definition of flipped classroom}

Flipped classroom is translated from "Flipped Class Model" or "Inverted Classroom" in English. The traditional teaching mode is that teachers give lectures in class, then assign homework and let students practice at home. Different from the traditional classroom teaching mode, this form is overturned in flipped classroom. Knowledge imparting is completed after class with the assistance 
of information technology, while knowledge internalization is completed with the help of teachers and classmates in class.

\subsection{The role of flipped classroom}

First, flipped classroom can cultivate students' ability to explore independently. Independent learning ability is one of the qualities that students should have. In flipped classroom, teachers will pay more attention to students' independent learning ability.

Second, it can cultivate students' ability of cooperative learning. In the flipped classroom environment, group cooperation is adopted to allow and encourage students to participate meaningfully. Flipped classroom provides participants with opportunities to communicate with their peers and various problem-solving strategies.

\subsection{Features of flipped classroom teaching}

The teaching of higher vocational colleges is generally composed of knowledge imparting and internalization, and the stages of knowledge imparting and internalization are different. However, the order of knowledge transmission and internalization is reversed in flipped classroom. There is shown in table 1.

Table 1 Comparison of factors in traditional classroom and flipped classroom teaching

\begin{tabular}{|c|c|c|}
\hline & Traditional classroom & Flipped classroom \\
\hline Teachers & $\begin{array}{l}\text { Knowledge imparts and } \\
\text { classroom manager }\end{array}$ & Learning mentor and facilitator \\
\hline Students & Passive receiver & Active researcher \\
\hline Teaching form & Lecture and homework & Study before class and classroom inquiry \\
\hline Teaching content & Teach knowledge & Explore problems \\
\hline $\begin{array}{l}\text { Technology } \\
\text { application }\end{array}$ & Content show & $\begin{array}{l}\text { Independent learning, communication and } \\
\text { reflection, collaborative discussion tools }\end{array}$ \\
\hline Evaluation way & Traditional paper test & Multiple angles, multiple ways \\
\hline
\end{tabular}

In flipped classroom, the passive audience is transformed into active learners, which facilitates the realization of personalized teaching. It is helpful for the cultivation of students' advanced critical thinking and problem-solving ability. Flipped classroom teaching mode is a typical application mode with high integration of information technology and curriculum.

\section{The important role of flipped classroom teaching in vocational colleges}

\subsection{Improving students' learning initiative}

Flipped classroom teaching mode brings forward classroom teaching to the pre-class. This teaching mode gives full play to the initiative of students. Students learn the learning content in pre-class, label and summarize the difficult problems and puzzling points, and finally interact with the teacher in class to solve problems. Students' initiative enhances the clarity of learning purpose. Take the study of management as an example, students watch the video content of management before class, and then communicate with teachers in class about the content they do not understand. In the whole process, students' autonomy and initiative have been dominant. This teaching method is implemented in the teaching of students, which will make learning purposeful and fruitful. 


\subsection{Changing the leading role of teachers}

Traditional education concept requires teachers to lead students' learning. However, flipped classroom advocates the people-oriented concept and takes students as the main body of learning. This mode has replaced the main role of teachers, who are the helper, guide and server of students' learning. They play a service role in students, education and management. Flipped classroom teaching saves teachers a lot of time, which allows them more time to improve teaching, such as innovating teaching methods, changing teaching concepts, improving teaching ideas, and better carrying out education activities.

\subsection{Improving teaching quality}

The traditional teaching mode is mainly taught by the whole class of teachers, and the students are in a passive position. The mastery and perception of knowledge is completely carried out after class. Flipped classroom teaching transforms teaching content into video teaching material for students to learn before class. When encountering difficult knowledge points, students in vocational colleges can interact with teachers in class to deepen their understanding. This kind of teaching mode has realized the knowledge to develop to the deeper direction.

\subsection{Improving students' learning efficiency}

There is still time for real activity. Flipped classroom gives full play to students' subjective initiative, from the perspective of teaching plan completion. In the process of group cooperation, the students who study well will lead the difficult students to make progress together, which promotes the improvement of students' academic performance. Flipped classroom has a significant effect, making students realize the happiness and honor of knowledge sharing among peers. At the same time, it changes the teaching concept of teachers and students and reduces the psychological pressure of teachers.

\section{Research on development countermeasures of flipped classroom teaching mode in vocational colleges}

\subsection{Improving teachers' professional ability}

Flipped classroom mainly focuses on the following three points. First, teachers make video courseware before class. Second, students use the Internet to watch video and learn in their spare time. Third, teachers and students communicate face to face in class and complete homework. So, video textbook design and production is very important. Video teaching material requirements are not only consistent with the teaching content and teaching objectives, but also has a certain level of interest, practicality and difficulty. Only in this way can students take the initiative to complete the exploration of new knowledge. This undoubtedly requires higher teaching quality and teaching ability. Teachers in higher vocational colleges are very weak, and their ability to use information technology is not high, such as information technology, multimedia technology, computer application technology and so on. So, it is difficult to achieve the desired recording effect in video design and production. At present, micro-course teaching mode is widely applied, and teachers in higher vocational colleges need stronger ability to make micro-course. This makes it difficult for teachers to form a good connection and concept conversion in a short time. In addition, after the liberation of classroom explanation, the classroom has become the main place for communication, discussion, summary, practice and expansion, which requires the same high quality of teachers. 
Vocational colleges need to improve the teaching effect of flipped classroom through the following ways. Such as, strengthen the transformation of teachers' concept, implement the people-oriented concept in the new quality education, change education concept, promote the reform of education with the service concept, and guide students to better practice and expand knowledge. Teachers need to learn to improve their ability of classroom organization, and also need to make full preparations for classes in extracurricular time. Only in this way can teachers fully mobilize students' enthusiasm to participate in classroom interaction. Because teachers need to spend more time and energy in designing, producing and preparing flipped classroom teaching content, and sometimes they need to take up more private time. So, the school needs to formulate a set of corresponding incentive policies to encourage teachers, so that they can participate in the application, communication and research of flipped classroom.

\subsection{Improving students' self-control}

The application of flipped classroom teaching mode requires students to have strong autonomy and self-control ability, so as to ensure the high quality of pre-class learning. However, most students enrolled by vocational colleges do not like learning, which is uncontrollable for self-learning video and summarizing the content that they are difficult to understand. This situation makes this teaching mode not effective. Higher vocational colleges should be equipped with monitoring platforms. And through these monitoring platforms, vocational colleges can form a good supervision mode. Through these ways, we can ensure that these students can complete the study of video or micro class earnestly and effectively. So, the school needs to build a flipped classroom learning system. Students can use their student id and password to log in for watching, and add questions and answers in the video broadcast process. Higher vocational colleges can also follow the class system through counselors. Counselors organize and urge students to watch video in groups or groups for learning.

\subsection{Strengthening facilities for ensuring student education}

Flipped classroom has high requirements for the improvement of information platform. Vocational colleges should speed up the construction of digital information campus to meet the needs of the implementation of flipped classroom. Higher vocational colleges should avoid excessive class hours, which will lead to students not having enough spare time to watch. Schools need to reduce class hours and encourage students to watch video. Students can be in the classroom or in the dormitory. Students can use mobile phones, tablets and other mobile terminals for learning. Higher vocational colleges can open the multimedia computer rooms of libraries and laboratories. In this way, video is offered to students with family difficulties or limited financial ability.

\section{Conclusions}

Flipped classroom teaching mode can be effectively applied in higher vocational colleges, which should meet the following conditions. Schools should ensure that information teaching conditions meet the standards. There is related to the quality of teaching resource production, which has an important impact on students' after-class learning effect. Students' independent learning ability is an important factor for the success of flipped classroom. Schools must take certain compulsory measures and formulate corresponding systems. No teaching mode is perfect. Only by constantly improving the teaching mode and promoting effective learning can the teaching mode conform to the trend of teaching reform. Vocational colleges should apply the "flipped classroom" teaching model to all kinds of teaching disciplines. Only in this way can flipped classroom teaching content 
be tested and enriched.

\section{References}

[1] Li kang. Survey on college students' employability and occupational quality requirements [J].New Oriental. 2009 (12): 46-49.

[2] Zhou road. Application of "flipped classroom" mode in information technology teaching [J].Modern reading (education), 2012, (24).

[3] Yu zhenhua. Problems and countermeasures in the implementation of flipped classroom teaching mode [J]. Teaching and management. 2015(33).

[4] Xie fei, ning miao, ma yuting, Yin sunliang. Problems and countermeasures of flipped classroom teaching method in higher vocational colleges [J]. Journal of jinhua vocational and technical college. 2014(06). 